\title{
CYTOKINES AND T-LYMPHOCYTE COUNT IN PATIENTS IN THE ACUTE AND CHRONIC PHASES OF Bartonella bacilliformis INFECTION IN AN ENDEMIC AREA IN PERU: A PILOT STUDY
}

\author{
Erick HUARCAYA (1), Ivan BEST (1), Juan RODRIGUEZ-TAFUR (2), Ciro MAGUIÑA (1), Nelson SOLÓRZANO (3), Julio MENACHO (4), \\ Douglas LOPEZ DE GUIMARAES (4), Jose CHAUCA (1) \& Palmira VENTOSILLA (1)
}

\begin{abstract}
SUMMARY
Human Bartonellosis has an acute phase characterized by fever and hemolytic anemia, and a chronic phase with bacillary angiomatosis-like lesions. This cross-sectional pilot study evaluated the immunology patterns using pre- and post-treatment samples in patients with Human Bartonellosis. Patients between five and 60 years of age, from endemic areas in Peru, in the acute or chronic phases were included. In patients in the acute phase of Bartonellosis a state of immune peripheral tolerance should be established for persistence of the infection. Our findings were that elevation of the anti-inflammatory cytokine IL-10 and numeric abnormalities of $\mathrm{CD}^{+}$and $\mathrm{CD} 8^{+} \mathrm{T}$-Lymphocyte counts correlated significantly with an unfavorable immune state. During the chronic phase, the elevated levels of IFN- $\gamma$ and IL-4 observed in our series correlated with previous findings of endothelial invasion of $B$. henselae in animal models.
\end{abstract}

KEYWORDS: Carrion's Disease; Human Bartonellosis; Cytokines; Immunology.

\section{INTRODUCTION}

Infection with Bartonella species has been associated with Carrion's Disease, Trench Fever, Cat Scratch Disease, bacillary angiomatosis, endocarditis, and bacillary peliosis ${ }^{21,22}$. In Peru, Carrion's Disease or Human Bartonellosis (HB) has been recorded since the times of preColumbian cultures ${ }^{1}$. The female sandfly of the genus Lutzomyia ssp. is the vector of transmission ${ }^{28}$, and has been mainly reported between 500 and 3200 meters of elevation ${ }^{21,28}$. The etiologic agent of HB is Bartonella bacilliformis, an aerobic, pleomorphic and monopolar flagellated Gramnegative bacterium which is surrounded by aggregative fimbriae ${ }^{22,24}$. These bacteria may produce an acute (Oroya Fever) or chronic (Peruvian Verruca) infection with different clinical presentations $\mathrm{s}^{21,22,28}$.

The acute phase (Oroya Fever) is characterized by fever and severe hemolytic anemia with hepatosplenomegaly, jaundice and pallor. The mortality rate of the acute phase varies between $1 \%$ in hospitalized patients and $88 \%$ in untreated patients ${ }^{21,28}$. Asymptomatic carriers have been described in endemic areas, with prevalence up to $5 \%$ in the population $^{21,22,28}$.

Complications of the acute phase include myocarditis, subacute pericarditis, neurobartonellosis, and co-infections with Salmonella sp., Toxoplasmosis, Tuberculosis, pneumococcal pneumonia, Pneumocystis jiroveci pneumonia, and Staphylococcus aureus sepsis ${ }^{21,22}$. As explanation, as early as 1926, Dr. Weiss in Peru theorized that an immune "anergic" state must exist during the HB infection based on clinical observation of severe co-infections and a failure in some patients to respond to the tuberculin skin test ${ }^{6,10,21,22,29}$. Non-infectious complications such as congestive heart failure, thrombocytopenia, severe anemia, seizures, intracranial hypertension, and multi-organ dysfunction have been reported ${ }^{21,22,28}$.

The chronic phase of Bartonellosis may follow the acute process, usually after one or two months ${ }^{2}$, and is characterized by the development of a single or hundreds of verrucas that may histopathologically resemble bacillary angiomatosis or Kaposi's sarcoma ${ }^{21,22,25,28}$. The verruca is characterized by angioblastic hyperplasia, activation of Langerhans cells, deposit of $\operatorname{IgM}$, IgA, and complement C3 in endothelial cells, with subsequent altered morphology and function ${ }^{6,28,33}$.

As a pilot study, we measured Th1/Th2 and regulatory cytokines, as well as $\mathrm{CD}^{+}$and $\mathrm{CD}^{+} \mathrm{T}$ cells in patients in the acute and chronic phases of $\mathrm{HB}$, to determine immunological patterns, differences, and data for future research.

\section{MATERIALS AND METHODS}

Patients and clinical evaluation: For this pilot study, patients were enrolled at a reference hospital in Lima-Peru, Hospital Nacional Cayetano Heredia, and two hospitals located in endemic areas for HB, Hospital

(1) Instituto de Medicina Tropical "Alexander von Humboldt", Universidad Peruana Cayetano Heredia, Lima, Peru.

(2) Pharmacology Section, Dynamic Sciences Department, Universidad Nacional Mayor de San Marcos, Lima, Peru.

(3) Hospital de Apoyo de Caraz, Ancash, Peru.

(4) Hospital Regional de Huaraz, Ancash, Peru.

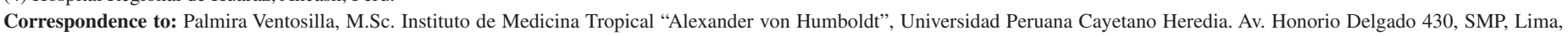
Peru. Phone: + 51-1-4823910, Fax: + 51-1-4823404. E-mail: palmira.ventosilla@upch.pe 


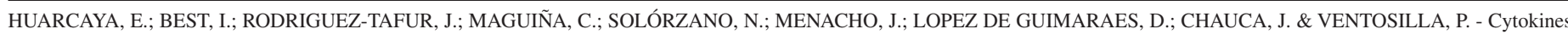
and T-lymphocyte count in patients in the acute and chronic phases of Bartonella bacilliformis infection in an endemic area in Peru: a pilot study. Rev. Inst. Med. Trop. Sao Paulo, 53(3): 149-54, 2011.

Regional de Huaraz and Hospital de Apoyo de Caraz, in Ancash-Peru (Fig. 1).

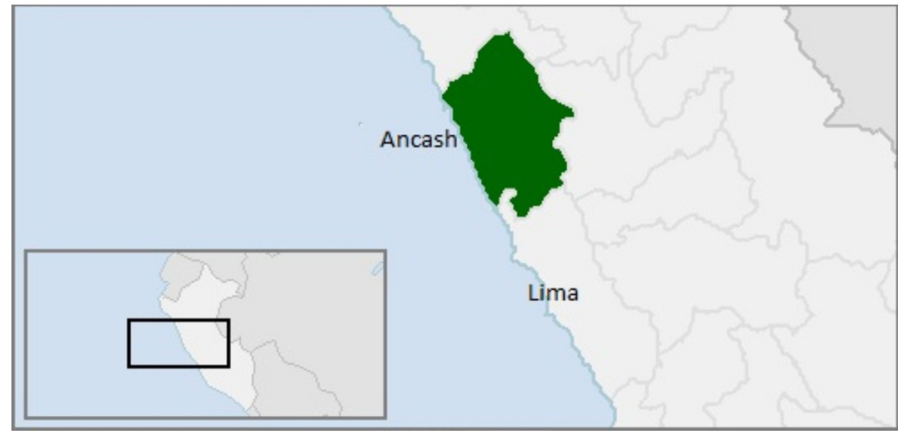

Fig. 1 - Map of endemic area in Peru

The patients were selected using the following criteria: aged between five and 60 years old, resident of endemic area, and clinical diagnosis of B. bacilliformis infection (acute or chronic), according to standard criteria of the Peruvian Ministry of Health ${ }^{28}$ and confirmed by peripheral smear and/or blood culture in patients with acute-phase HB. The exclusion criteria were: pregnancy or amenorrhea during the previous month, use of antibiotics in the previous two weeks ${ }^{7,11}$, previous use of oral or systemic steroids, chemotherapy, cancer, and co-infection with HIV or other immunodeficiency. Healthy subjects considered as controls were non-pregnant residents from Lima, without previous infection of $B$. bacilliformis, recent illnesses, or previous history of primary or secondary immunodeficiency. No controls were considered from the endemic area because of the possibility of including asymptomatic patients infected with B. bacilliformis ${ }^{21}$.

Patients or tutors signed an informed consent, previously approved by the Ethics Committee of the Universidad Peruana Cayetano de Heredia (ID CIE: 04095).

Immunohistochemical analysis and cytokines measurement: Specimens were collected upon enrollment in the study, at discharge from the hospital for those admitted, or during the follow up visit for those outpatients. The specimens were collected in $10 \mathrm{~mL}$ vacutainer tubes with EDTA, and sent to Lima for analysis.

The immunological studies were performed in the Laboratory of Immunology of the "Alexander von Humboldt" Institute of Tropical Medicine (IMT-AvH), of the Universidad Peruana Cayetano Heredia in Lima-Peru. The absolute number of $\mathrm{CD}^{+}$and $\mathrm{CD}^{+} \mathrm{T}$ cells were measured in peripheral blood using saturating concentrations of combinations of anti-CD3-peridinin chlorophyll protein (PerCP), antiCD4-fluorescein isothiocyanate (FITC) and anti-CD8-phycoerythrin (PE) (Becton Dickinson, Erembodegem, Belgium), according to the manufacturer's instructions. Data were analyzed using the CellQuest software (Becton Dickinson, San Diego) in a fluorescence activated cell sorter (FACS Calibur) (Becton Dickinson, San Diego).

The levels of IFN- $\gamma$, TNF- $\alpha$, IL-4, IL-10, and TGF- $\beta$ in the patient's plasma were evaluated using commercial Kits (BD OptEIA ${ }^{\mathrm{TM}}$ ELISA kits- $($ )). The concentrations of cytokines (in $\mathrm{pg} / \mathrm{mL}$ ) and TGF- $\beta$ (in $\mathrm{ng} / \mathrm{mL}$ ) were measured using an ELISA reader (Biorad-®).
Data analysis: Because most of the variables showed non-normal distribution (Table 1 and Table 2), the Cytokines and $\mathrm{CD} 4^{+} / \mathrm{CD}^{+} \mathrm{T}$-cells counts from acute and chronic patients, both before and after treatment, were compared using the non-parametric Wilcoxon test. Differences among pre-treatment, post-treatment, and control samples were evaluated using the non-parametric Kruskal-Wallis test. We considered every difference for which the probability of similarity was less than 0.05 $(p<0.05)$ as being significant.

Table 1

Descriptive statistics of immunology pattern in patients with acute-phase human Bartonellosis

\begin{tabular}{lcccc}
\hline \multicolumn{5}{c}{ A. Pre Treatment } \\
\hline WBC & $\mathrm{n}$ & minimum & maximum & median \\
CD4 ${ }^{+}$ & 09 & 5300 & 10250 & $7054.77^{*}$ \\
CD8 & 13 & 81 & 1279 & 675.00 \\
CD4/CD8 & 13 & 75 & 3285 & 455.00 \\
IFN- $\gamma$ & 13 & 0.36 & 3.48 & 1.65 \\
TNF- $\alpha$ & 11 & 13.13 & 1248.75 & 50.63 \\
IL-4 & 12 & 0.00 & 3.61 & $1.39^{*}$ \\
IL-10 & 12 & 0.00 & 22.33 & 3.85 \\
TGF- $\beta$ & 12 & 7.20 & 343.46 & 49.30 \\
\hline \multicolumn{5}{c}{ B. Post Treatment } \\
\hline WBC & 09 & 12.25 & 27.70 & 15.45 \\
\hline CD4 & minimum & maximum & median \\
CD8 ${ }^{+}$ & 06 & 5500 & 9800 & $7641.67^{*}$ \\
CD4/CD8 & 06 & 261 & 1871 & $929.33^{*}$ \\
IFN- $\gamma$ & 06 & 245 & 3765 & 1230.00 \\
TNF- $\alpha$ & 06 & 0.27 & 1.82 & 0.88 \\
IL-4 & 06 & 6.88 & 50.52 & $24.15^{*}$ \\
IL-10 & 06 & 0.00 & 30.25 & 1.95 \\
TGF- $\beta$ & 05 & 0.00 & 4.40 & 2.16 \\
\hline & 06 & 2.81 & 107.44 & 14.51 \\
\hline
\end{tabular}

* mean

\section{RESULTS}

General Data: Patients were included in this study between October 2004 and June 2006. Nine healthy subjects were included as controls.

Thirty patients in the acute phase were initially included in the study. Subsequently, three of them were excluded for pregnancy, and fourteen others whose infection was not confirmed (negative peripheral smear and blood culture). Finally, 13 patients were included in the analysis. The mean age of the 13 patients with acute-phase HB was 26.4 years (range: 5 - 49 years old), with a mean duration of illness of 16.3 days (range: 2 30 days). Because hemolyzed samples and samples that arrived after 12 hours from the endemic area were not analyzed, only eight post-treatment blood samples were included in the study. The descriptive statistics are shown in Table 1.

Forty -two patients were initially included with diagnosis of chronic- 


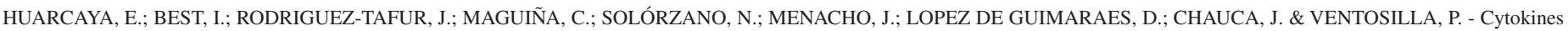
and T-lymphocyte count in patients in the acute and chronic phases of Bartonella bacilliformis infection in an endemic area in Peru: a pilot study. Rev. Inst. Med. Trop. Sao Paulo, 53(3): 149-54, 2011

Table 2

Descriptive statistics of immunology pattern in patients with chronic-phase human Bartonellosis

\begin{tabular}{|c|c|c|c|c|}
\hline \multicolumn{5}{|c|}{ A. Pre Treatment } \\
\hline & $\mathrm{n}$ & minimum & maximum & median \\
\hline WBC & 15 & 2200 & 10700 & $5953.33 *$ \\
\hline $\mathrm{CD}_{4}^{+}$ & 18 & 188 & 1952 & 813.00 \\
\hline $\mathrm{CD}^{+}$ & 18 & 181 & 1548 & $676.28 *$ \\
\hline $\mathrm{CD} 4 / \mathrm{CD} 8$ & 18 & 0.21 & 3.28 & $1.51 *$ \\
\hline IFN- $\gamma$ & 21 & 0.00 & 790.67 & 17.50 \\
\hline TNF- $\alpha$ & 21 & 0.00 & 6.22 & 0.32 \\
\hline IL-4 & 20 & 0.00 & 42.65 & 1.65 \\
\hline IL-10 & 21 & 0.60 & 105.24 & 14.36 \\
\hline TGF- $\beta$ & 20 & 11.60 & 117.55 & 19.55 \\
\hline \multicolumn{5}{|c|}{ B. Post Treatment } \\
\hline & $\mathrm{n}$ & minimum & maximum & median \\
\hline WBC & 04 & 4700 & 7100 & 5100.00 \\
\hline $\mathrm{CD}^{+}$ & 05 & 791 & 1175 & 880.00 \\
\hline $\mathrm{CD}^{+}$ & 05 & 574 & 997 & 744.00 \\
\hline CD4/CD8 & 05 & 0.82 & 1.47 & 1.38 \\
\hline IFN- $\gamma$ & 10 & 0.00 & 134.00 & 9.78 \\
\hline TNF- $\alpha$ & 10 & 0.00 & 2.99 & $0.88 *$ \\
\hline IL-4 & 11 & 0.00 & 135.00 & 1.47 \\
\hline IL-10 & 11 & 0.00 & 18.90 & 3.20 \\
\hline TGF- $\beta$ & 00 & & & \\
\hline
\end{tabular}

phase HB. However, 21 patients were excluded from the analysis (twenty because of previous use of antibiotics and one for an age outside the inclusion criterion). Post-treatment samples were obtained from eleven patients. The mean age of the patients in the chronic phase was 27.2 years (range: 9 - 51 years old), and the mean duration of illness was 42 days (range: 14 - 120 days). The descriptive statistics are shown in Table 2.

Quantitative analysis of Cytokines in plasma: The differences in pre-treatment values obtained in the acute phase patients at time of enrollment and those obtained in the controls were not statistically significant for white blood cells (WBC) count, IFN- $\gamma$, TNF- $\alpha$ level, IL-4, and TGF- $\beta$, except for IL-10 $(p<0.05)$. Similar findings were observed in the post-treatment samples compared with controls, with $p<0.05$ for IL-10.

The differences in pre-treatment samples from acute-phase (Table 1 ) and chronic-phase (Table 2) patients were not statistically significant for WBC count, TNF- $\alpha$ level, TGF- $\beta$, and IL-4, except for IFN- $\gamma(p=$ $0.018)$ and IL-10 $(p=0.011)$. The post-treatment samples from acutephase (Table 1) and chronic-phase (Table 2) patients were not statistically significantly different for WBC count, TNF- $\alpha$ level, IFN- $\gamma$, TGF- $\beta$, and IL-4, except for IL-10 ( $p=0.048)$.

The pre-treatment samples analysis from acute phase cases and controls were significantly different only for IL-10 ( $p=0.003)$. The differences in post-treatment samples between the acute phase cases and controls were significant only for IL-10 ( $p=0.007$ ) (Fig. 2).
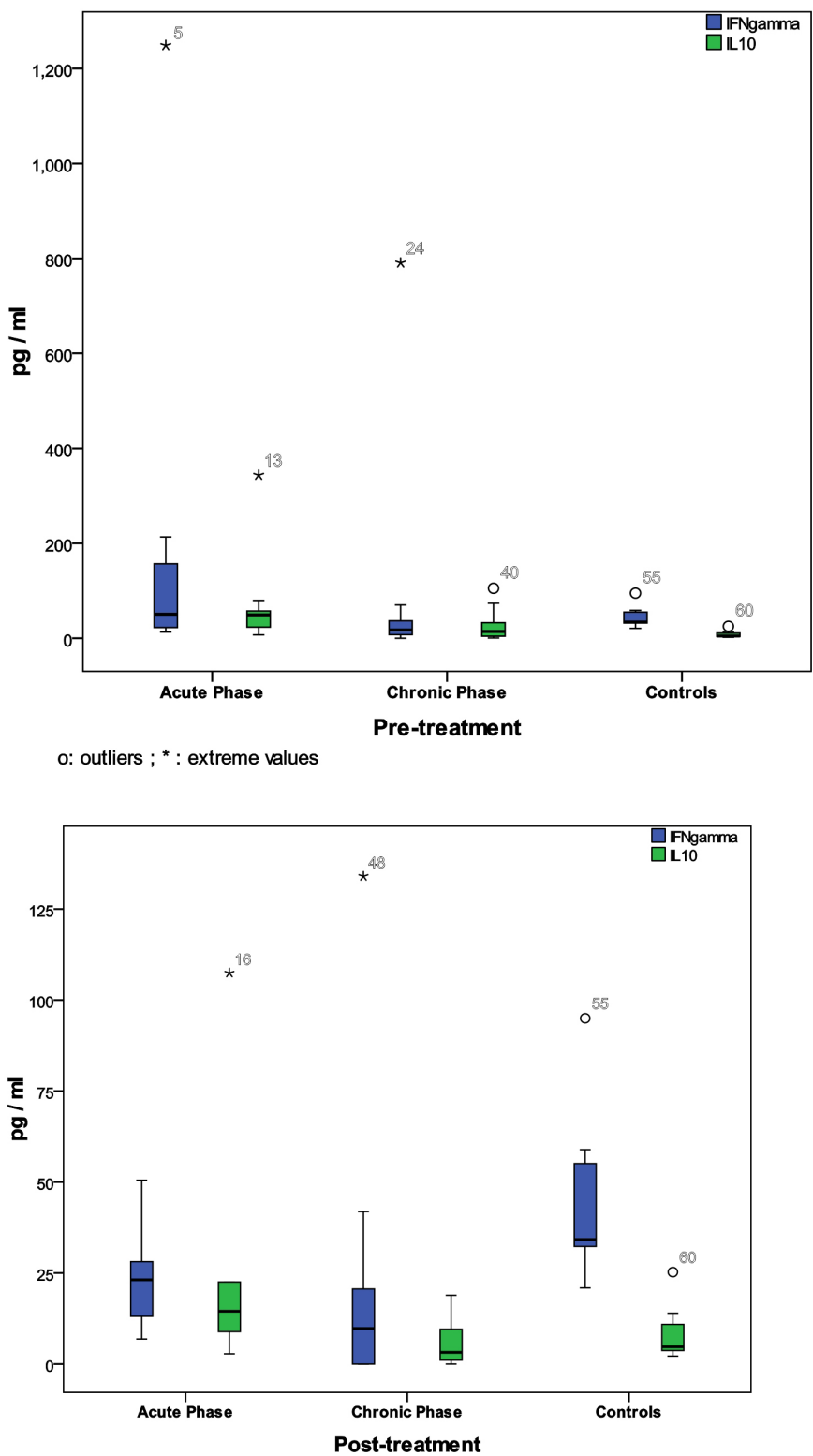

o: outliers ; * : extreme values

Fig. 2 - Cytokine' counts in patients with human Bartonellosis.

Four of the 13 cases of acute-phase HB were considered complicated, due to co-infection with Epstein-Barr virus and CMV, a case of pericarditis (with $78 \%$ of parasitemia), a case of neuro-bartonellosis (with $98 \%$ of parasitemia), and a death. The patient who died showed the highest level of IL-10 in the series ( $343.46 \mathrm{pg} / \mathrm{mL})$. No numeric abnormalities in T-Lymphocyte count were seen in these patients (Table 1).

The difference between pre-treatment samples from chronic-phase patients and samples from controls were not statistically significant 


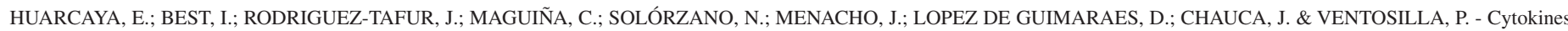
and T-lymphocyte count in patients in the acute and chronic phases of Bartonella bacilliformis infection in an endemic area in Peru: a pilot study. Rev. Inst. Med. Trop. Sao Paulo, 53(3): 149-54, 2011.

for WBC count, TNF- $\alpha$ level, and IL-10, except for $p$-value of IFN- $\gamma$ $(p=0.07)$ and IL-4 $(p=0.015)$. The post-treatment samples from the chronic-phase cases and controls were significantly different only in $\operatorname{IFN}-\gamma(p=0.010)$.

Quantitative analysis of T-Lymphocyte cell count in plasma: During the acute phase, the lowest CD4+ T-lymphocyte count was 81 . Four patients in total had a CD4 ${ }^{+} \mathrm{T}$-lymphocytes count below 150 in the acute-phase HB sample (Table1). One patient had a CD8 ${ }^{+}$T-lymphocyte count of 75 , with a normal count of $\mathrm{CD}^{+}(261$ cell/ $\mu \mathrm{L})$ and the highest count of IFN- $\gamma(1248.75 \mathrm{pg} / \mathrm{mL})$. No numeric abnormalities were noted in patients with chronic-phase HB (Table 2). Pre-treatment samples from
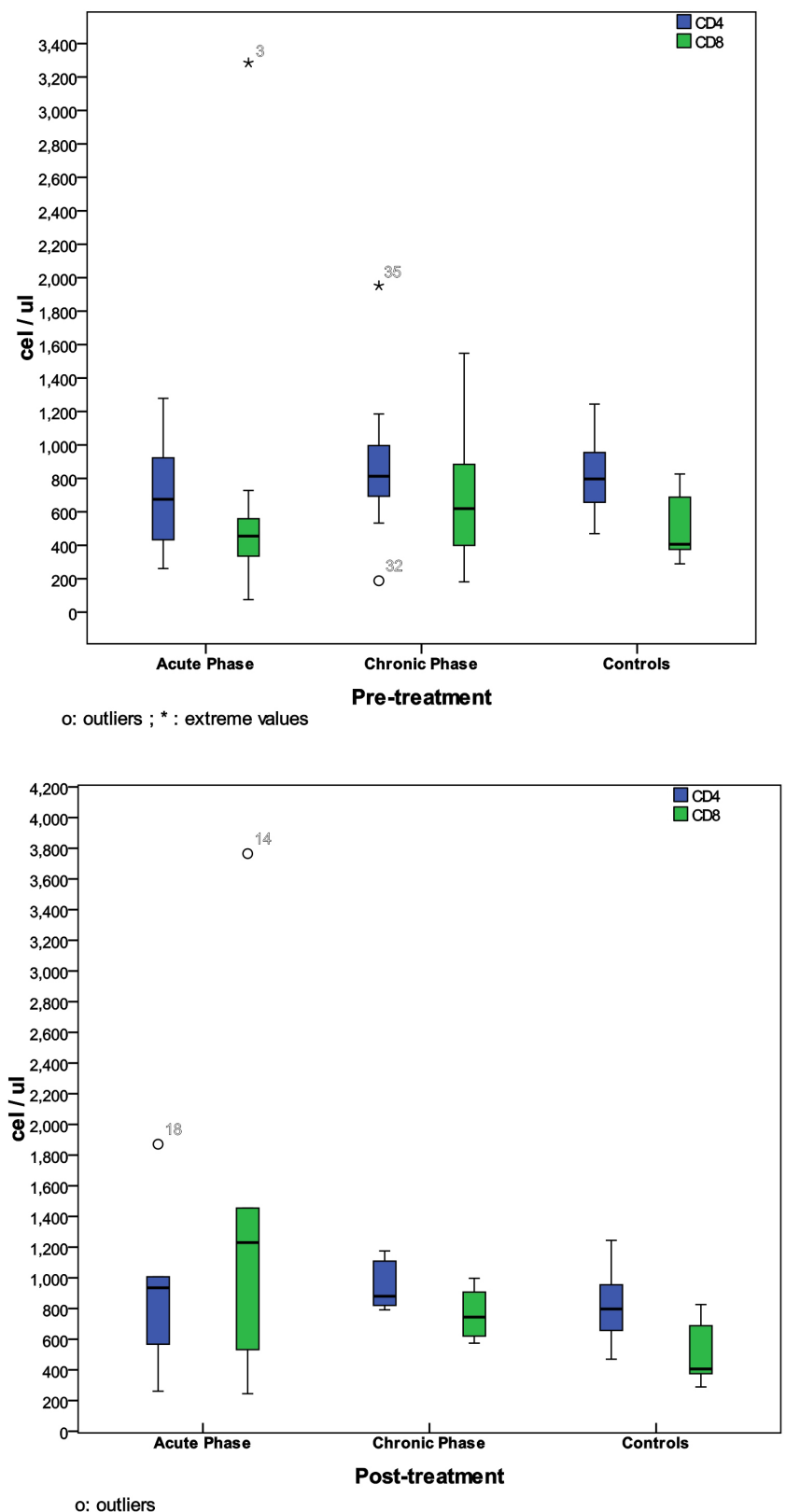

Fig. 3 - T-lymphocyte cells count in patients with human Bartonellosis. acute cases and from the controls showed no statistical difference in either $\mathrm{CD}^{+}{ }^{+}$or $\mathrm{CD}^{+} \mathrm{T}$-lymphocyte count. The post-treatment samples from chronic cases were significantly higher than the controls in CD8 ${ }^{+}$ count with $p=0.042$ (Fig. 3).

\section{DISCUSSION}

During the previous several decades, studies have focused on the effects of B. bacilliformis on the host. Based on studies performed during the 1980's and 1990's it is accepted that during the acute-phase of the disease the humoral response is activated ${ }^{6,28}$. The antigen-presenting cells are activated, as is the complement cascade (including the classic and alternative pathway), due to antigenic proteins exposed on red blood cells, as well as increased IgM levels $\mathrm{s}^{3,6,24,29}$. Clinically focused studies have shown that the acute phase of HB may be manifested in the host with a diversity of severities, from asymptomatic to acute life-threatening hemolytic anemia with multiple complications ${ }^{6,21,22,28}$ characteristics of patients with IRIS. A similar variety in presentations and severities due to Bartonella henselae has been shown to have a close correlation with the host's immune status ${ }^{30}$. Interestingly, HENRIQUEZ et al. ${ }^{12}$ described a case of persistent $B$. bacilliformis bacteremia in a situation of altered immunological state. It has been reported that the intensity of the inflammatory response in any case, depends on previous exposure to B. bacilliformi $^{22}$ and probably on genetic predisposition ${ }^{32}$.

Recently the significance of Th1-cell derived cytokines in resistance to bacterial invasion has been seen to play important roles during $B$. henselae infection and in the induction of angiogenesis ${ }^{27,30}$, a process that may explain the effective phagocytic function in the immunocompetent individual is responsible for the localized, non-systemic expression of Cat Scratch Disease ${ }^{14,30}$. Due to limited research in HB in this area, we looked for similarities, but no clear Th1- or Th2- cell derived cytokines were found. However, similar to an induction of IFN- $\gamma$ and IL-12 (not measured in our study) observed with $B$. henselae stimulation in rodents ${ }^{26}$, our series of patients showed a significant initial elevation of IFN- $\gamma$ (Fig. 2) and a non-significant elevation of TNF- $\alpha$ (Table 1) as part of the inflammatory process that also can be seen in other gram-negative infections ${ }^{4,19}$.

Although the immunopathology that develops during HB is unclear, some theoretical models have been proposed ${ }^{6,32}$. A few important findings described recently implicated the role of Toll-like receptors (TLRs). TLRs are part of an important family of innate immune receptors that recognize pathogen-associated molecular patterns, but is not activated by flagellin molecules of $B$. bacilliformis $^{2,31}$. Thus the bacteria avoid being recognized by epithelial cells and dendritic cells, and thus do not activate the pro-inflammatory response ${ }^{14}$. The bacterias are therefore able to bind and to invade red blood cells $s^{6,21,28}$. In addition, the lack of activation of dendritic cells will prevent the reversal of Treg cells in anergic states ${ }^{15,34}$. Thus, preventing the activation of dendritic cells, B. bacilliformis may establish and maintain an immune peripheral tolerance in the host ${ }^{6,32}$. Finally, this impairment in the cellular immunity favors the reactivation of intracellular infections such as tuberculosis and Toxoplasmosis, which are commonly reported in the endemic areas ${ }^{21,22}$.

The phenomenon of peripheral tolerance may be enhanced by cytokines such as IL-10, which by disarming innate as well as adaptive responses creates conditions for microbe persistence and chronic 


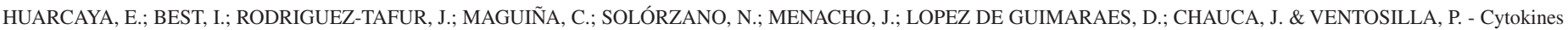

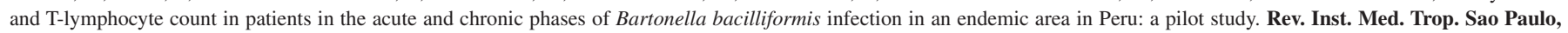
53(3): 149-54, 2011.

infectious disease ${ }^{23}$. Elevation of IL-10 is due mainly to CD $43^{+} \mathrm{CD} 4^{+}$ T-cells, which are important in the equilibrium between Th1 and Th2 responses ${ }^{18}$. Th2 cytokines, including IL-10, inhibit the secretion of pro-inflammatory cytokines ${ }^{19,20}$. Given these observations, our finding of statistically significant elevated levels of IL-10 in patients with acute-phase HB (Fig. 2) may not be surprising. Unfortunately, we did not find significant differences in concentration of pre-treatment TGFbeta, which is also involved in immune suppression and angiogenesis ${ }^{9,35}$. These observations suggest further studies, including the measurement of cytokines in directly stimulated Lymphocytes with $B$. bacilliformis antigens which will avoid the possibility of erroneous attribution of cytokine levels due to other multiple factors other than the bacteria of interest. In addition, because of its short half-life in plasma ${ }^{5,17}$, it is important to measure IL-10 immediately after sample collection.

Descriptions of anergy and clinical complications seen only in immunocompromised patients, as in AIDS, were the reasons why T-Lymphocytes were counted in early studies. PATRUCCO ${ }^{29}$, was the first to report patients with a decreased number of $\mathrm{CD}^{+}{ }^{+} \mathrm{T}$-Lymphocytes, but also, and more importantly, deficiencies in their function. Among our patients, significantly low counts of $\mathrm{CD}^{+}$and $\mathrm{CD} 8^{+} \mathrm{T}$-Lymphocytes were found, that are resolved following appropriate treatment (Tables 1 and 2). Cytotoxic T-Lymphocytes may be required to clear bacteria from sequestered sites such as the vascular endothelial tissue and lymphoid $\operatorname{organs}^{12,14}$. This transitory numeric abnormality in T-cell count may also explain co-infections and other complications previously described ${ }^{21,22,28}$. Further studies with a more adequate sample size may confirm this finding, as well as the functional compromise in the cellular immune response described initially by PATRUCCO ${ }^{29}$.

The eruptive phase of $\mathrm{HB}$ is characterized by endothelial compromise, by mechanisms that are still unclear, but it is known that $B$. bacilliformis, $B$. henselae, and $B$. quintana can produce similar angiogenic factors ${ }^{16,21,22}$ and that $B$. bacilliformis is captured by endothelial cells in a process that involves the GTPase Rho protein ${ }^{3,8}$. Interestingly, the vascular proliferation as seen in the chronic-phase of HB resembles the morphologic findings in patients with AIDS, Kaposi's sarcoma, and Bacillary Angiomatosis, all of which exist only in immune-deficient states ${ }^{6,10}$.

In our group of patients in the chronic phase we found significantly elevated levels of IFN- $\gamma$ and IL-4 (Fig. 2 and Table 2). These finding may be explained by the active role of the humoral immune reaction in limiting the bacterial presence to the vascular epithelial tissue and the role of IFN- $\gamma$ in the enhancing phagocytic activity ${ }^{14}$. These findings also resemble observations in an animal model with elevated levels of IFN $\gamma$ - and IL-4 after a systemic inoculation with $B$. henselae antigen ${ }^{13,14}$.

In summary, the varied severity of clinical presentation by patients with acute-phase HB should be considered to be related to the patient's immune status, with a state of immune peripheral tolerance needed to establish persistent infection ${ }^{2,14,15,34}$. Our findings of statistically significant elevation of the anti-inflammatory cytokine IL-10 and numeric abnormalities in the $\mathrm{CD}^{+}$and $\mathrm{CD}^{+} \mathrm{T}$-Lymphocyte counts correlates with an immune state unfavorable for infection clearance. The chronic phase of HB resembles histologically diseases prevalent in immune-deficient conditions, such as Kaposi's sarcoma, and Bacillary Angiomatosis ${ }^{6,10,16}$. However, there is no clear explanation for this resemblance. Finally, elevated levels of IFN- $\gamma$ and IL-4 observed in our work correlated positively with previous findings in animal models of B. henselae endothelial invasion ${ }^{26}$.

\section{RESUMEN}

\section{Citoquinas y recuento de Linfocitos $T$ en pacientes en fase aguda y crónica de infección por Bartonella bacilliformis, en una área endémica del Perú: estudio piloto}

La Bartonelosis Humana, tiene una fase aguda caracterizada por fiebre y anemia hemolítica, así como una fase crónica con lesiones semejantes a angiomatosis bacilar. En un estudio transversal piloto los patrones inmunológicos en pacientes con Bartonelosis Humana fueron estudiados mediante muestras pre y post tratamiento. Pacientes entre 5 y 60 años en fase aguda y crónica fueron incluidos en área endémica del Perú. En aquellos pacientes con fase aguda, una fase de tolerancia inmunológica periférica es necesaria para la persistencia de la infección. Los hallazgos de significativa elevación de citoquina anti-inflamatoria (IL-10) y anormalidades numéricas en el recuentos de Linfocitos T CD4 ${ }^{+}$ y $\mathrm{CD}^{+}$correlacionan con un estado inmune que favorece la infección. Durante la fase crónica, elevados niveles de INF- $\gamma$ y IL-4 observados en la serie de pacientes correlacionan con previos hallazgos en modelos animales que favorecen la invasión del endotelio por $B$. henselae.

\section{ACKNOWLEDGEMENTS}

The authors thank biologists from the immunology laboratory of the "Alexander von Humboldt" Tropical Medicine Institute for their collaboration, Dr. Augusto Tarazona and Dr. Carlos Seas for their help with patient recruitments, Dr. Betty Skipper for reviewing the statistical analysis, and Dr Krishna Radnakrishna PhD for the review of the manuscript. This study was partially financed by the Instituto Fundacion Hipolito Unanue.

\section{REFERENCES}

1. Allison MJ, Pezzia A, Gerszten E, Mendoza D. A case of Carrion's Disease associated with human sacrifice from Huari culture of southern Peru. Am J Phys Anthropol. 1974;41:295-300.

2. Andersen-Nissen E; Smith KD, Strobe KL, Barrett SL, Cookson BT, Logan SM, et al. Evasion of Toll-like receptor 5 by flagellated bacteria. Proc Natl Acad Sci (USA). 2005; 102:9247-52.

3. Buckles E, McGinnis H. Interaction of Bartonella bacilliformis with human erythrocytes membrane proteins. Microb Pathog. 2000;29:165-74.

4. Casey LC, Balk RA, Bone RC. Plasma cytokine and endotoxin levels correlate with survival in patients with the sepsis syndrome. Ann Intern Med. 1993;119:771-8.

5. Chernoff AE, Granowitz EV, Shapiro L, Vannier E, Lonnemann G, Angel JB, et al. A randomized, controlled trial of IL-10 in humans inhibition of inflammatory cytokines production and immune responses. J Immunol. 1995;154:5492-9.

6. Contreras G. Historia y aportes al conocimiento de la inmunologia de la Verruga Peruana. (Presentación de Incorporación a la Academia Nacional de Medicina). Lima: Imprenta Universidad Nacional Mayor de San Marcos; 1994.

7. Dalhoff A, Shalit I. Immunomodulatory effects of quinolones. Lancet Infect Dis 2003;3:359-71.

8. Dehio C. Bartonella interactions with endothelial cells and erythrocytes. Trend Microbiol. 2001;9:279-85. 
HUARCAYA, E.; BEST, I.; RODRIGUEZ-TAFUR, J.; MAGUIÑA, C.; SOLÓRZANO, N.; MENACHO, J.; LOPEZ DE GUIMARAES, D.; CHAUCA, J. \& VENTOSILLA, P. - Cytokines and T-lymphocyte count in patients in the acute and chronic phases of Bartonella bacilliformis infection in an endemic area in Peru: a pilot study. Rev. Inst. Med. Trop. Sao Paulo, 53(3): 149-54, 2011.

9. Ferrari G, Cook BD, Terushkin V, Pintucci G, Mignatti P. Transforming growth factorbeta 1 (TGF-B1) induces angiogenesis through vascular endothelial growth factor (VEGF)-mediated apoptosis. J Cell Physiol. 2009;219:449-58.

10. Garcia-Caceres U, Garcia FU. Bartonellosis: an immunodepressive disease and the life of Daniel Alcides Carrion. Am J Clin Pathol. 1991;95:58-66.

11. Gogos CA, Skoutelis A, Lekkou A, Drosou E, Starakis I, Marangos MN, et al. Comparative effect of Ciprofloxacin and Ceftazidime on cytokine production in patients with severe sepsis caused by gram-negative bacteria. Antimicrob Agents Chemother. 2004;48:2793-8.

12. Henriquez C, Hinojosa JC, Ventosilla P, Infante B, Merello J, Mallqui V, et al. Report of an unusual case of persistent bacteremia by Bartonella bacilliformis in a splenectomized patient. Am J Trop Med Hyg. 2004;71:53-5.

13. Karem KL, Dubois K, McGill S, Regnery RL. Characterization of Bartonella henselaespecific immunity in BALB/c mice. Immunology. 1999;97:352-8.

14. Karem KL. Immune aspect of Bartonella. Crit Rev Microbiol. 2000;26:133-45.

15. Kubo T, Hatton RD, Oliver J, Liu X, Elson CO, Weaver CT. Regulatory T cell suppression and anergy are differentially regulated by proinflammatory cytokines produced by TLR-activated dendritic cells. J Immunol. 2004;173:7249-58.

16. Leboit PE, Berger TG, Egbert BM, Beckstead JH, Yen TS, Stoler MH. Bacillary Angiomatosis, the histopathology and differential diagnostic of a pseudoneoplastic infection in patients with Human Immunodeficiency Virus disease. Am J Surg Pathol. 1989;13:909-20.

17. Li L, Elliot JF, Mosmann TR. IL-10 inhibits cytokine production, vascular leakage, and swelling during T Helper 1 cell-induced delayed-type hypersensitivity. J Immunol. 1994; $153: 967-78$

18. Lund R, Ahlfors H, Kainonen E, Lahermaa AM, Dixon C, Lahesmaa R. Identification of genes involved in the initiation of human Th1 or Th2 cell commitment. Eur J Immunol. 2005;35:3307-19.

19. Marchant A, Deviere J, Byl B, De Groote D, Vincent JL, Goldman M. Interleukin-10 production during septicemia. Lancet. 1994;343:707-8.

20. Marchant A, Alegre ML, Hakim A, Pierard G, Marecaux G, Friedman G, et al. Clinical and biological significance of interleukin-10 plasma levels in patients with septic shock. J Clin Immunol. 1995;15:266-73.

21. Maguiña C. Bartonelosis o Enfermedad de Carrión, nuevos aspectos de una vieja enfermedad. Lima: A.F.A Editores Importadores; 1998.
22. Maguiña C, Garcia PJ, Gotuzzo E, Cordero L, Spach DH. Bartonellosis (Carrion's Disease) in the modern era. Clin Infect Dis. 2001;33:772-9.

23. Mege JL, Meghari S, Honstettre A, Capo C, Raoult D. The two faces of interleukin 10 in human infectious diseases. Lancet Infect Dis. 2006;6:557-69.

24. Minnick MF, Mitchell SJ, McAllister SJ. Cell entry and the pathogenesis of Bartonella infection. Trends Microbiol. 1996;4:342-6.

25. Montoya M, Maguiña C, Vigo B, Caparo R, Briceño E, Astorga L. et al. Bartonelosis en el Valle Sagrado de los Incas (Cusco). Bol Soc Per Med Interna. 1998;11:170-6.

26. Musso T, Badolato R, Ravarino D, Stornello S, Panzanelli O, Merlino C, et al. Interaction of Bartonella henselae with the murine macrophage cell line J774: infection and proinflammatory response. Infect Immun. 2001;69:5974-80.

27. Orme IM, Roberts AD, Griffin JP, Abrams JS. Cytokine secretion by CD4 T lymphocytes acquired in response to Mycobacterium tuberculosis infection. J Immunol. 1993;151:518-25.

28. Pachas P. La Bartonelosis en el Perú. Módulos Técnicos, Oficina General de Epidemiología (OGE). Lima: Instituto Nacional de Salud; 2000.

29. Patrucco R. Estudio de los parámetros inmunológicos en pacientes portadores de la Enfermedad de Carrión. Diagnostico. 1993;12:138-44.

30. Resto-Ruiz S, Burgess A, Anderson BE. The role of the host immune response in pathogenesis of Bartonella henselae. DNA Cell Biol. 2003;22:431-40.

31. Rolain JM, Novelli S, Ventosilla P, Maguina C, Guerra H, Raoult D. Immunofluorescence detection of Bartonella bacilliformis flagella in vitro and in vivo in human red blood cells as viewed by laser confocal microscope. Ann NY Acad Sci. 2003;990:581-4.

32. Ticona E, Huaroto L, Garcia Y, Vargas L, Madariaga MG. The pathophysiology of the acute phase of human Bartonellosis resembles AIDS. Medical Hypotheses. 2010;74:45-9.

33. Verma A, Davis G, Ihler GM. Formation of stress fibers in human endothelial cells infected with Bartonella bacilliformis associated with altered morphology, impaired migration, and defects in cell morphogenesis. Cell Microbiol. 2001;3:169-80.

34. Vermi W, Fachetti F, Riboldi E, Heine H, Scutera S, Stornello S, et al. Role of dendritic cell-derived CXCL 13 in the pathogenesis of Bartonella henselae rich granuloma. Blood. 2006;107:454-62.

35. Wan Y, Flavell RA. TGF- $\beta$ and regulatory $\mathrm{T}$ cell in immunity and autoimmunity. J Clin Immunol. 2008;28:647-59.

Received: 8 August 2010

Accepted: 11 March 2011 